\title{
Oxygen release, microleakage and shear bond strength of composite restorations after home dental bleaching
}

\author{
Liberação de oxigênio, microinfiltração e resistência de união \\ ao cisalhamento em restaurações com resina composta \\ após clareamento dental caseiro
}

\begin{abstract}
Purpose: This in vitro study evaluated the effect of home dental bleaching on oxygen release, shear bond strength to enamel, and microleakage of direct composite restorations.

Methods: Forty bovine incisors were used for oxygen dissolved titration by means of iodometric methods modified by azide iodine and 26 for the shear bond strength and microleakage tests. For titration the teeth were divided into four groups: T1 - bleached and titrated after $24 \mathrm{~h}$; T2 - bleached and titrated after 48 h; T3 - unbleached and titrated after 24 h; T4 - unbleached and titrated after $48 \mathrm{~h}$. T5 group served as control for the initial oxygen release rate. To analyze shear bond strength and microleakage, the teeth were randomly divided into two groups: CM1 - bleached; CM2 - unbleached. The bleaching agent Opalescence 15\% (Ultradent, South Jordan, UT, USA) was applied for $8 \mathrm{~h}$ per day for three weeks. Z 250 (3M-ESPE, St. Paul, MN, USA) composite and Single Bond (3M-ESPE, St. Paul, MN, USA) adhesive were used for the composite restoration procedures.

Results: There was an increase in oxygen release during the first $24 \mathrm{~h}$ post bleaching (ANOVA, $P=0.0001$ ). The bleached teeth showed a decrease in shear bond strength (Student's $\dagger$ test, $P=0.0001)$. The microleakage scores increased with bleaching independently from the examiner (Wilcoxon's test: 1. $\mathrm{P}=0.0003 ; 2 \mathrm{P}=0.0023 ; 3$. $\mathrm{P}=0.0029$ ).

Conclusion: Considerable variation was noticed in the results of oxygen release, as well as in the results of shear bond strength and microleakage on bleached teeth.
\end{abstract}

Key words: Bleaching; microleakage; shear; oxygen; carbamide peroxide; composite

\section{Resumo}

Objetivo: Avaliaram-se os efeitos do clareamento dental caseiro na liberação de oxigênio a partir de dentes clareados, na resistência de união ao cisalhamento e microinfiltração de restaurações com resina composta.

Metodologia: Foram selecionados 40 incisivos bovinos para titulação dos níveis de oxigênio pelo método iodométrico e 26 dentes para resistência de união e microinfiltração. Para titulação os dentes foram divididos em 4 grupos: T1- clareado e titulado após 24 h; T2- clareado e titulado após 48 h; T3- não clareado e titulado após 24 h; T4- não clareado e titulado após 48 h. No grupo T5 não se usaram dentes, servindo como controle inicial do teor de oxigênio. Para cisalhamento associado a microinfiltração dividiram-se aleatoriamente os dentes em 2 grupos: CM1 - clareado; CM2- não clareado. O regime de tratamento clareador (Opalescense a 15\%, Ultradent, South Jordan, UT, USA) foi de $8 \mathrm{~h}$ por dia durante 3 semanas. Para as restaurações utilizou-se a resina Z250 (3M-ESPE, St. Paul, MN, USA) com adesivo Single Bond (3M-ESPE, St. Paul, MN, USA)

Resultados: Houve aumento significativo na liberação de oxigênio durante nas primeiras 24 h pós clareamento (ANOVA, $P=0,0001$ ). $O$ teste $†$ de Student confirmou diminuição da resistência de união para o grupo clareado $(P=0,0001)$. Houve significante aumento na microinfiltração no grupo clareado, independentemente do examinador (teste de Wilcoxon: 1. $P=0,0003$; $2 . P=0,0023$; 3. $P=0,0029$ ).

Conclusão: Há considerável variação nos resultados de liberação de oxigênio, resistência de união e microinfiltração em dentes submetidos a clareamento dental caseiro.

Palavras-chaves: Clareamento; microinfiltração; cisalhamento; oxigênio; peróxido de carbamida; resina composta

\section{Marcelo Tomás de Oliveira a Mauro Amaral Caldeira de Andrade b Márcia Michels ${ }^{c}$}

- Mestrado em Saúde, Universidade do Sul de Santa Catarina (UNISUL), Tubarão, SC, Brasil b Departamento de Dentística, Universidade Federal de Santa Catarina, Florian[ópolis, SC, Brasil

c Laboratório de Análise do CENTEC, Universidade do Sul de Santa Catarina (UNISUL), Tubarão, SC, Brasil

\author{
Correspondence: \\ Marcelo Tomás de Oliveira \\ Av. Marcolino Martins Cabral, 1960 - Vila Moema \\ Tubarão, SC - Brasil \\ 88705-000 \\ E-mail:marcelo.oliveira@unisul.br \\ Received: August 9, 2010 \\ Accepted: November 28, 2010 \\ Conflict of Interest Statement: The authors state \\ that there are no financial and personal conflicts of \\ interest that could have inappropriately influenced \\ their work. \\ Copyright: (C) 2011 Oliveira et al.; licensee \\ EDIPUCRS. This is an Open Access article distributed \\ under the terms of the Creative Commons Attribution- \\ Noncommercial-No Derivative Works 3.0 Unported \\ License.
}




\section{Introduction}

Home bleaching treatment with a solution of hydrogen peroxide or carbamide is a popular alternative for improving dental aesthetics. In products based on hydrogen peroxide, the bleaching agent is in contact with saliva, and other organic fluids dissociation occurs in water and oxygen (1). However, bleaching products based on carbamide peroxide dissociate into urea and hydrogen peroxide. Despite this difference, the active bleaching agent in the products is oxygen, possibly because of its low molecular weight $(2,3)$. In fact, it penetrates the dental hard tissues and removes the pigments through diffusion (1).

Since the products do not have a bleaching effect on the color of composite restorative materials, it is frequently necessary to replace the adhesive aesthetic restorative fillings after a bleaching treatment (2). Also, changes in the characteristic interface between the adhesive and the bleached enamel may cause severe alterations in the properties of these restorations (3-10).

Residual oxygen may be incorporated into the enamel during the bleaching treatment and would be responsible for altering the polymerization of the adhesive systems, causing a reduction of sheer bond strength and an increase in marginal microleakage $(2,4,11)$. However, measurements performed through microanalysis in the subsuperficial layer of the enamel did not present significant variations in the levels of oxygen, which refuted its association with the adhesive alterations (12). Yet, no conclusive evidence is still available in the literature regarding this possible side effect of home dental bleaching.

This study was conducted to evaluate oxygen release from bleached teeth through a chemical analysis called titration of Winkler or iodometric method which is a classic method of chemical humid analysis, where the sample is diluted (13). In this case, differently from the microanalysis, the presence of oxygen in the dental structure is not measured, but the concentration of oxygen that migrated from the teeth to the solution. Using the same bleaching treatment, the effects of this oxygen release on the sheer bond strength and the marginal microleakage of composite restorations were evaluated. The null hypothesis tested in this study was that the home dental bleaching would not affect the adhesive interface as measured by shear bond strength and microleakage. The other null hypothesis was that bleached and unbleached teeth release the same amount of oxygen.

\section{Methods}

The study protocol was approved by the institutional review board.

\section{Shear Bond Strength and Microleakage Tests}

In the mechanical simulations of shear bond strength to enamel and the evaluation of marginal microleakage, 26 bovine incisors were used. As showed in Fig. 1, both microleakage and shear tests used the same teeth, in different areas.

Firstly, the teeth were sectioned through the cementoenamel junction and randomly divided into two groups. The roots were removed, the crowns were embedded in acrylic resin, and the specimens were polished with silicon carbide sandpaper up to 1200-grit (Fig. 1A). The teeth were bleached with Opalescence 15\% (Ultradent, South Jordan, UT, USA) for $8 \mathrm{~h}$ a day for 3 weeks and stored in an artificial saliva solution (12) at $37^{\circ} \mathrm{C}$ in a humidifier, between bleaching session.

Six hours after the completion of treatment, the teeth were prepared. For the microleakage a cavity preparation was made in the cervical area using a 1132A drill. Cavity preparation was $5 \mathrm{~mm}$ wide, $2 \mathrm{~mm}$ high and $1.5 \mathrm{~mm}$ deep, with all the surrounding walls in enamel (Fig. 1B).

The surface of the bovine teeth, including the prepared cavity, was covered with adhesive tape except for an opening about $5 \mathrm{~mm}$ in diameter between the middle and incisal third of the crown (Fig. 1C). Over this area, the Single Bond adhesive (3M-ESPE, St. Paul, MN, USA) was used according to the manufacturer's recommendations. The composite resin Z250 (3M-ESPE, St. Paul, MN, USA) was used to simulate a restoration in the specimens for the shear bond strength test. Afterwards, the adhesive tape was removed, and the cavity to be used for microleakage evaluation was cleaned and restored by applying the same adhesive and resin composite. The incremental technique was adopted, and the oblique increments were approximately $2 \mathrm{~mm}$ in thickness (Fig. 1D). The light-curing unit used was the Optilux unit (Demetron/ Kerr, Danbury, CT, USA) with light intensity of $500 \mathrm{~mW} /$ $\mathrm{cm}^{2}$, monitored by means of a radiometer (Demetron/Kerr, Danbury, CT, USA). The specimens were stored in $20 \mathrm{~mL}$ of artificial saliva at $37^{\circ} \mathrm{C}(12)$. Twenty-four hours later the cervical restorations were polished with Soflex sandpaper disks (3M-ESPE, St. Paul, MN, USA) and thermocycled for 300 cycles at temperatures between $5^{\circ} \mathrm{C}$ and $55^{\circ} \mathrm{C}$ (14).

Shear bond strength test was accomplished using an Instron 4444 machine (Canton, MA, USA) at a constant speed of $0.5 \mathrm{~mm} / \mathrm{min}$. Immediately after the shear bond strength test, the failure mode was evaluated using magnifying glass (Stemi DV4/DR, Carl Zeiss, Göttingen, Germany), at a magnification of $32 x$.

The cervical restorations were isolated with nail polish (Fig. 1E), leaving only an area of $2 \mathrm{~mm}$ around the restoration. They were then placed in a dark plastic container, containing $20 \mathrm{~mL}$ of a 50/50 mix of silver nitrate and stored for $4 \mathrm{~h}$ at $37^{\circ} \mathrm{C}$. Afterwards, the specimens were exposed to a radiographic developing solution (Kodak) for a period of $6 \mathrm{~h}$ and then to a $250 \mathrm{~W}$ "Photoflood lamp" (G.E of México S.A.) for $4 \mathrm{~h}$, for complete exposure of the silver ions in the solution (15). The specimens were then cut to $1.5 \mathrm{~mm}$ from the mesial and distal wall of the cavity using a lab cut machine (Buehler Isomet 1000, Buehler, Lake Bluff, IL, USA) at a speed of $400 \mathrm{rpm}$ (Fig. 1F and Fig. 1G). The surface was observed using a magnifying glass (Stemi DV4/ DR, Carl Zeiss, Göttingen, Germany) (Fig. 1H), and the 
examiner used scores from 0 to 4 to grade the microleakage degree, according to a standardized schematic design (Fig. 1I). To determine the specimen's degree of microleakage, three independent examiners evaluated each specimen and considered the surface with the largest score. The data on shear bond strength to enamel and microleakage were analyzed by Student's t test and Wilcoxon test, at the significance level of 0.01 .

\section{Titration of dissolved oxygen}

To analyze oxygen release, 40 bovine incisors were used. After the teeth were cleaned, their apex was sealed with resin cement (Enforce, Dentsply, Konstanz, Germany) and the roots were painted with nail polish. They were randomly divided into 4 groups (T1, T2, T3, and T4) (Fig. 1J). Group T5 had no teeth and was used as a control group to measure the initial concentration of oxygen of the titled solution.

The bleaching protocol was the same as described for the shear bond strength and microleakage tests. Groups T1 and $\mathrm{T} 2$ were bleached and groups T3 and T4 were not bleached and stored in artificial saliva (Fig. 1K). After bleaching treatment, all teeth were immediately brushed and placed in a Hale tube containing $250 \mathrm{~mL}$ of deionized water. Groups $\mathrm{T} 1$ and $\mathrm{T} 3$ were stored for $24 \mathrm{~h}$ and groups $\mathrm{T} 3$ and T4 for $48 \mathrm{~h}$ (Fig. 1L). The titrimetric analysis of dissolved oxygen modified by azida iodine was performed (13). Data were analyzed by ANOVA, at the significance level of 0.01 .

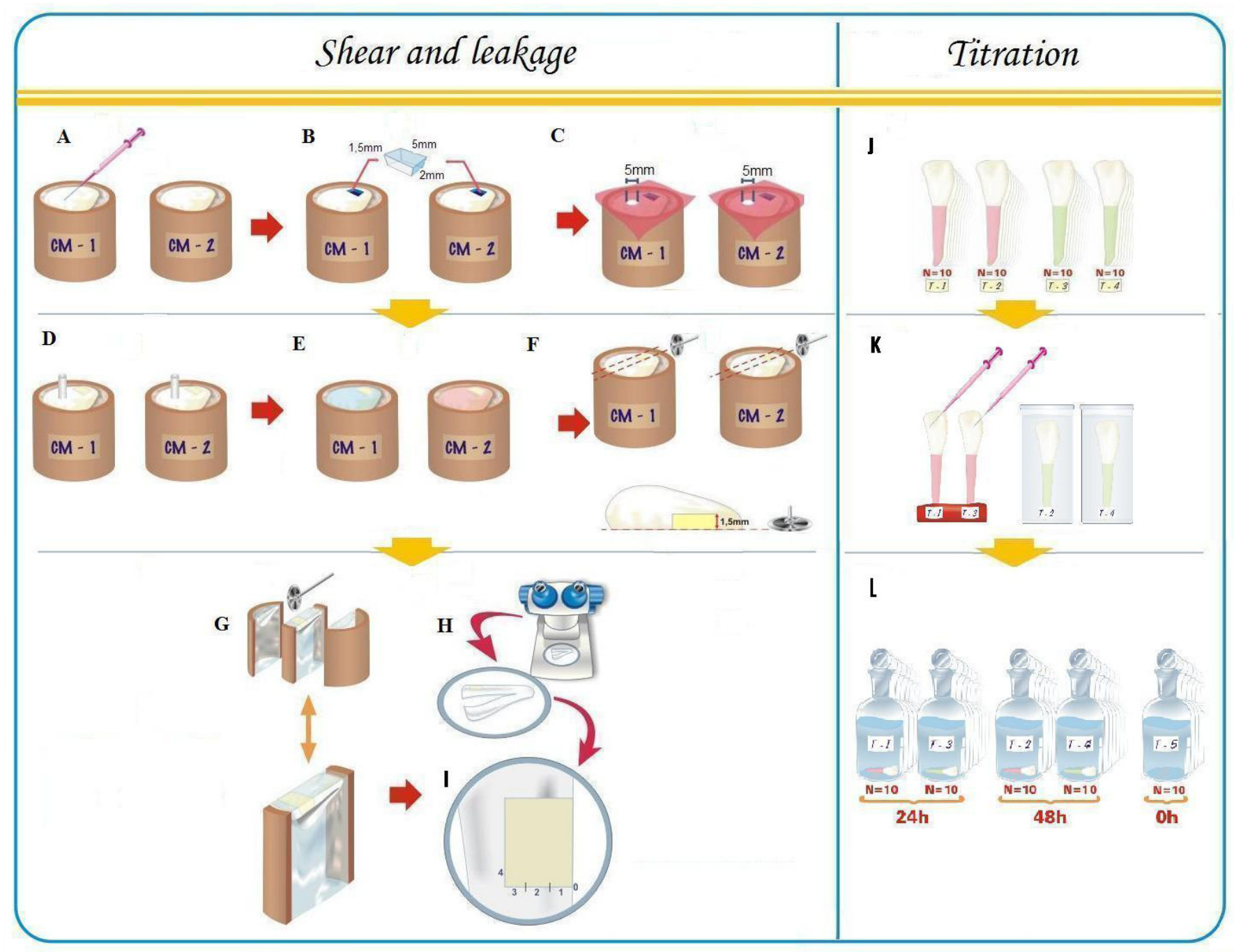

Fig. 1. Schematic design of the experiment. Shear bond strength and microleakage tests: A. Tooth clinical crowns are embedded in resin. B. Cavities are prepared for the microleakage analysis. C. Surface isolation with adhesive tape to limit the area for the shear strength test. D. Specimen is prepared for the shear bond strength test, with the cavity restored. E. Isolation of the teeth to test the infiltration of the tressed solution. F. Location of the section cuts. G. Selected surface for the test. H. Microscopic analysis. I. Scores of microleakage. Titration analysis: J. Bovines teeth are divided into groups. K. Bleached groups received bleach solution and control groups (T3 and T4) are stored in artificial saliva. L. The teeth are stored in the Hale recipient for the titration (with the inclusion of T5 group). 


\section{Results}

Means of dissolved oxygen $(\mathrm{mg} / \mathrm{L})$ are shown in Table 1. The results of ANOVA showed that groups T1 and T2 had significantly larger volumes of oxygen than the other groups $(P=0.0001)$. However, there was no difference between groups, i.e., there was no increase in oxygen level between 24 and 48 hours. The means of unbleached groups, T3 and T4, and the control group, T5, did not differ from each other significantly, and they showed the smallest means of dissolved oxygen.

The results of the test of shear bond strength to the enamel are shown in Table 2. The bleached group had significant lower bond strength in comparison with the unbleached group $(P=0.0001)$. Table 3 shows the failure mode with a predominance of adhesive failure in the bleached group, and

Table 1. Oxygen release levels obtained by the titration analysis of oxygen dissolved in azide iodine.

\begin{tabular}{cccc}
\hline Group & Treatment & $\begin{array}{c}\text { Analysis } \\
\text { Moment }\end{array}$ & $\begin{array}{c}\text { Oxygen Release } \\
(\mathrm{mg} / \mathrm{L})^{*}\end{array}$ \\
\hline T1 & Bleached & After $24 \mathrm{~h}$ & $14.7 \pm 2.55^{\mathrm{a}}$ \\
T2 & Bleached & After 48h & $13.5 \pm 2.53^{\mathrm{a}}$ \\
T3 & Unbleached & After $24 \mathrm{~h}$ & $6.2 \pm 1.23^{\mathrm{b}}$ \\
T4 & Unbleached & After 48h & $6.1 \pm 1.24^{\mathrm{b}}$ \\
T5 & Control & Immediately & $6.3 \pm 1.29 \mathrm{~b}$ \\
\hline
\end{tabular}

* Means followed by the same letter do not differ from each other.

Table 2. Results of the shear bond strength test to the bleached and unbleached enamel.

\begin{tabular}{lcc}
\hline & $\begin{array}{c}\text { Bleached enamel } \\
\text { (CM1) }\end{array}$ & $\begin{array}{c}\text { Unbleached enamel } \\
\text { (CM2) }\end{array}$ \\
\hline Mean* & $16.79 a$ & $26.99 \mathrm{~b}$ \\
Standard Deviation & 5.75 & 4.77 \\
Coefficient of variation & 0.34 & 0.18 \\
\hline
\end{tabular}

* Means followed by a different letter differ from each other.

Table 3. Failure mode observed in the study groups after the shear bond strength test.

\begin{tabular}{lcc}
\hline \multicolumn{1}{c}{ Failure Mode } & $\begin{array}{c}\text { Bleached } \\
\text { group (\%) }\end{array}$ & $\begin{array}{c}\text { Unbleached } \\
\text { group (\%) }\end{array}$ \\
\hline Adhesive & 61.6 & 30.7 \\
Adhesive/Cohesive in enamel & - & 7.7 \\
Adhesive/Cohesive in composite & 30.7 & 53.7 \\
Cohesive in enamel & - & 7.7 \\
Cohesive in composite & 7.7 & 7.7 \\
\hline
\end{tabular}

Table 4. Statistic results of each examiner regarding microleakage scores.

\begin{tabular}{cccc}
\hline Comparison & Examiner & P-value & Results \\
\hline 1 and 2 & 1 & 0.0003 & Refuse $\mathrm{H}_{0}$ \\
1 and 2 & 2 & 0.0023 & Refuse $\mathrm{H}_{0}$ \\
1 and 2 & 3 & 0.0029 & Refuse $\mathrm{H}_{0}$ \\
\hline
\end{tabular}

mixed failure (Adhesive/Cohesive failure in composite) in the unbleached group. Table 4 shows the statistical results of each examiner for the microleakage scores: the groups were statistically different regardless of the examiner $\left(\mathrm{H}_{0}\right.$ was rejected).

\section{Discussion}

Dental bleaching is a result of diffusion of pigments through the release of oxygen associated with peroxide. However, not all of the oxygen present in this mechanism is eliminated. Some amount of oxygen can be retained inside the enamel, dentin or even pulp tissue (16). In the superficial layer of the enamel, Pellet et al. (16) did not observe variation in the concentration of oxygen. In contrast, our results showed that bleached teeth are able to release significant amounts of oxygen in the first 24 hours following the bleaching treatment. In this study, we evaluated the release of oxygen without taking into account the possible location of its retention, thus supporting the deductive reasoning that residual oxygen has no effect $(2,4,11,16)$, as well as supporting the hypothesis of its retention in deeper layers of the tooth structure (12).

The evaluation of oxygen dissolved through iodometric methods modified by azide, differently from the microanalysis, does not measure the presence of oxygen in the dental hard tissue, but the concentration of the oxygen that migrated from the bovine tooth into the solution $(17,18)$. In fact, the azide modification effectively removes interference caused by nitrite, which is the most common interference in biological samples (13).

The interaction between adhesive and residual oxygen affects polymerization and results in a pattern of changes in the interface of bonding material to enamel $(2,12)$. The physical consequences of this alteration are the reduction of bond strength to enamel (Table 2) and reduction in the quality of the marginal seal of the composite restorations (Table 3). All of these changes are possible causes for the premature failure of composite filling materials placed in recently bleached teeth. In an attempt to control these effects, some authors showed promising results treating bleached teeth with a deoxidizing agent of sodium ascorbate(11). However, the literature presents controversial results on the ability of adhesive systems with different types of solvent, and this alternative does not fully support its clinical application $(19,20)$.

The period of time required for residual oxygen to be eliminated, and the values of shear bond strength to recover to normal still generate disagreement $(3,6,8,11)$. In spite of this, waiting a certain period after bleaching still seems to be the safest way to control the bleaching side effects. In this analysis, we observed that the release of oxygen occurs during the first 24 hours after bleaching, because no difference occurs between 24 and 48 hours. For this reason, it has been assumed that, after the initial 24-hour period, we should not experience more negative affects at the adhesive interface. However, there are several factors present in the 
oral cavity (biofilm and salivary flow) that can influence the rate of stored oxygen release in the enamel. Therefore, a 24hour period may be an insufficient length of time to evaluate all the possible effects of home dental bleaching. Further studies should assess other variables that could influence the ultimate clinical results of home dental bleaching.

\section{Conclusions}

According to the methodology used and results, it can be concluded that:

1. Teeth bleached with $15 \%$ carbamide peroxide for 8 hours a day for 3 weeks and restored after 6 hours with composite, have decreased enamel shear bond strength and increased marginal microleakage.

2. Teeth bleached with $15 \%$ carbamide peroxide release significantly larger amounts of oxygen post-bleaching treatment compared with unbleached teeth.

3. The large amount of oxygen release probably occurs during the first $24 \mathrm{~h}$, because there is no difference in the measurements made after the first 24 and after 48 hours.

4. There is evidence that the oxygen release after bleaching would be responsible for alterations in the physical properties of the dental interface with a composite restoration.
References
1. haywood VB, Heymann HO. Nigthguard vital bleaching. Quintessence Int 1989; 20:173-6.

2. Titley KC, Torneck CD, Smith DC, Chermec R, Adbifar A. Scanning electron microscopy observations on the penetration and structure of resin tags in bleached and unbleached bovine enamel. J Endod 1991;17:222-7.

3. McGuckin RS, Thurmond BA, Osovitz S. Enamel shear bond strengths after vital bleaching. Am Dent J 1992;5:216-22.

4. Titley KC, Torneck CD, Ruse ND, Krmec D. Adhesion of a resin composite to bleached and unbleached human enamel. J Dent Res 1993;19:324-33.

5. Garcia-Godoy F, Dodge WW, Donohue M, O'Quinn JA. Composite resin bond strength after enamel bleaching. Oper Dent 1993;18:144-7.

6. Dishman MV, Covey DA, Baughan LW.The effects of peroxide bleaching on composite to enamel bond strength. Dent Mater 1994;9:33-6.

7. Josey AL, Meyers IA, Romaniuk K, Simons Al. The effect of a vital bleaching technique on enamel surface morphology and the bonding of composite resin to enamel. J Oral Rehabil 1996;23:244-50.

8. Spyrides GM, Perdigao J, Pagani C, Spyrides SM. Effect of Whitening on dentin bonding. J Esthet Dent 2000;12:264-70.

9. Shinohara MS, Rodrigues JA, Pimenta LA. In vitro microleakage of composite restorations after nonvital bleaching. Quintessence Int 2001;32:413-7.

10. Uluapaki H, Benderli Y, Uluapaki I. Effect of pre- and postoperative bleaching on marginal leakage of amalgam and composite restorations. Quintessence Int 2003;34:505-8.

11. Lai SC, Tay FR, Cheung GS. Reversal of compromised bonding in bleaching enamel. J Dent Res 2002; 81:477-81.

12. Perdigao J, Francci C, Swift EJ Jr, Ambrose WW, Lopes M. Ultra-morphological study of the interaction of dental adhesives with carbamide peroxide-bleached enamel. Am J Dent 1998; 11:445-9.

13. Eaton DA, Clesceri LS, Greenberg AE. Standard Methods 1995; 19:497-8.

14. Mandras RH, Retief D, Russel CM. The effects of thermal and oclusal stresses on the microleakage of glass-ionomer-resin composite hybrid materials. Quintessence Int 1991;7:63-7.

15. Retief DH. Standard laboratory adhesion tests. Am J Dent 1991;4:231-6.

16. Thitinanthapan W, Satamanont P, Vongsavan N. In vitro penetration of the pulp chamber by three brands of carbamide peroxide. J Esthet Dent 1999;1 1:259-64.

17. Vogel Al. Quantitative Chemistry Analysis. Rio de Janeiro: Guanabara Koogan, 1992.

18. Manhemeir WA. Materials Microscopy: an introduction. Brazilian Microscopy Society $2002 ; 10: 2-12$

19. Bargui N, Godwin N. Reducing the adverse effect of bleaching on composite-enamel bond. J Esthet Dent 1994; 6:157-61.

20. Sung EC, Cham SM, Mito R, Caputto AA. Effect of a carbamide peroxide bleaching on the shear bond strength of composite dental bonding agent enhanced enamel. J Prosthet Dent 1999; 2:595-8.

21. McGuking RS, Thurmond BA, Osovitz S. Enamel shear bond strengths after vital bleaching Am J Dent 1992;5:216-22. 